NASA/TM-2002-211834

IECEC-2002-20155

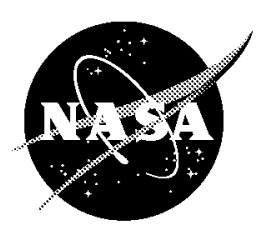

\title{
Multi-Junction Thin-Film Solar Cells on Flexible Substrates for Space Power
}

Aloysius F. Hepp

Glenn Research Center, Cleveland, Ohio

Mark Smith

Ohio Aerospace Institute, Brook Park, Ohio

John H. Scofield

Oberlin College, Oberlin, Ohio

John E. Dickman

Glenn Research Center, Cleveland, Ohio

Gregory B. Lush

University of Texas at El Paso, El Paso, Texas

Donald L. Morel and Christos Ferekides

University of South Florida, Tampa, Florida

Neelkanth G. Dhere

University of Central Florida, Orlando, Florida 
Since its founding, NASA has been dedicated to the advancement of aeronautics and space science. The NASA Scientific and Technical Information (STI) Program Office plays a key part in helping NASA maintain this important role.

The NASA STI Program Office is operated by Langley Research Center, the Lead Center for NASA's scientific and technical information. The NASA STI Program Office provides access to the NASA STI Database, the largest collection of aeronautical and space science STI in the world. The Program Office is also NASA's institutional mechanism for disseminating the results of its research and development activities. These results are published by NASA in the NASA STI Report Series, which includes the following report types:

- TECHNICAL PUBLICATION. Reports of completed research or a major significant phase of research that present the results of NASA programs and include extensive data or theoretical analysis. Includes compilations of significant scientific and technical data and information deemed to be of continuing reference value. NASA's counterpart of peerreviewed formal professional papers but has less stringent limitations on manuscript length and extent of graphic presentations.

- TECHNICAL MEMORANDUM. Scientific and technical findings that are preliminary or of specialized interest, e.g., quick release reports, working papers, and bibliographies that contain minimal annotation. Does not contain extensive analysis.

- CONTRACTOR REPORT. Scientific and technical findings by NASA-sponsored contractors and grantees.
- CONFERENCE PUBLICATION. Collected papers from scientific and technical conferences, symposia, seminars, or other meetings sponsored or cosponsored by NASA.

- SPECIAL PUBLICATION. Scientific, technical, or historical information from NASA programs, projects, and missions, often concerned with subjects having substantial public interest.

- TECHNICAL TRANSLATION. Englishlanguage translations of foreign scientific and technical material pertinent to NASA's mission.

Specialized services that complement the STI Program Office's diverse offerings include creating custom thesauri, building customized databases, organizing and publishing research results ... even providing videos.

For more information about the NASA STI Program Office, see the following:

- Access the NASA STI Program Home Page at http://wwzo.sti.nasa.gov

- E-mail your question via the Internet to help@stinasa.gov

- Fax your question to the NASA Access Help Desk at 301-621-0134

- Telephone the NASA Access Help Desk at 301-621-0390

- Write to: NASA Access Help Desk NASA Center for AeroSpace Information 7121 Standard Drive Hanover, MD 21076 


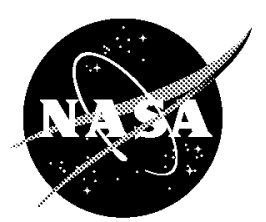

\section{Multi-Junction Thin-Film Solar Cells on Flexible Substrates for Space Power}

Aloysius F. Hepp

Glenn Research Center, Cleveland, Ohio

Mark Smith

Ohio Aerospace Institute, Brook Park, Ohio

John H. Scofield

Oberlin College, Oberlin, Ohio

John E. Dickman

Glenn Research Center, Cleveland, Ohio

Gregory B. Lush

University of Texas at El Paso, El Paso, Texas

Donald L. Morel and Christos Ferekides

University of South Florida, Tampa, Florida

Neelkanth G. Dhere

University of Central Florida, Orlando, Florida

Prepared for the

37th Intersociety Energy Conversion. Engineering Conference

sponsored by the Institute of Electrical and Electronics Engineers, Electron Devices Society Washington, DC, July 28-August 2, 2002

National Aeronautics and

Space Administration

Glenn Research Center 


\section{Acknowledgments}

Funding from NASA GRC is acknowledged for NCC3-800 (OAI), NCC3-712 (FSEC), and NAG3-2614 (USF).

This report contains preliminary findings, subject to revision as analysis proceeds.

Trade names or manufacturers' names are used in this report for identification only. This usage does not constitute an official endorsement, either expressed or implied, by the National Aeronautics and Space Administration.

Available from

NASA Center for Aerospace Information 7121 Standard Drive

Hanover, MD 21076
National Technical Information Service 5285 Port Royal Road Springfield, VA 22100

Available electronically at http://gltrs.grcnasa.gov 


\title{
MULTI-JUNCTION THIN-FILM SOLAR CELLS ON FLEXIBLE SUBSTRATES FOR SPACE POWER
}

\author{
Aloysius F. Hepp \\ National Aeronautics and Space Administration \\ Glenn Research Center \\ Cleveland, Ohio 44135 \\ Mark A. Smith \\ Ohio Aerospace Institute \\ Brook Park, Ohio 44142 \\ John H. Scofield \\ Oberlin College \\ Oberlin, Ohio 44074 \\ John E. Dickman \\ National Aeronautics and Space Administration \\ Glenn Research Center \\ Cleveland, Ohio 44135 \\ Gregory B. Lush \\ University of Texas at El Paso \\ El Paso, Texas 79968 \\ Donald L. Morel and Christos Ferekides \\ University of South Florida \\ Tampa, Florida 33620 \\ Neelkanth G. Dhere \\ University of Central Florida \\ Orlando, Florida 32816
}

\begin{abstract}
The ultimate objective of the thin-film program at NASA GRC is development of a $20 \%$ AMO thin-film device technology with high power/weight ratio. Several approaches are outlined to improve overall device efficiency and power/weight ratio. One approach involves the use of very lightweight flexible substrates such as polyimides (i.e. Kapton ${ }^{T M}$ ) or metal foil. Also, a compound semiconductor tandem device structure that can meet this objective is proposed and simulated using Analysis of Microelectronic and Photonic Structures (AMPS). AMPS modeling of current devices in tandem format indicate that AMO efficiencies near $20 \%$ can be achieved. And with improvements in materials, efficiencies approaching $25 \%$ are achievable. Several important technical issues need to be resolved to realize these complex devices: development of a wide bandgap material with good electronic properties, development of transparent contacts, and targeting a 2-terminal device structure (with more complicated processing and tunnel junction) or 4-terminal device. Recent progress in the NASA GRC program is outlined.
\end{abstract}

\section{INTRODUCTION}

Concepts for future space platforms include very large satellites such as solar power satellite (SPS) down to very small satellites; ${ }^{1,2}$ long-term plans envisage swarms of distributed, autonomous, small satellites termed microsats or even nanosats. Solar electric propulsion (SEP) technology that uses propulsion by accelerated ions has been successfully demonstrated in Deep Space $1 .^{2}$

Photovoltaic (PV) arrays will continue to be a key source for power generation in space. While $\mathrm{Si}$ and GaAs PV technologies continue to play a vital role in space, there are two areas in which improvement is sought: mass-specific power (MSP) or power/weight ratio and radiation hardness. Both materials suffer in this regard because they are based upon bulk materials, and $\mathrm{Si}$ is limited to single junction efficiencies. Solar cells based on thin-film materials offer the promise of much higher MSP and much lower cost. However, for space applications, a 15\% or greater AMO efficiency $(\eta)$ may be required. ${ }^{3}$ The leading thin-film materials - amorphous $\mathrm{Si}, \mathrm{CulnS \textrm {S } _ { 2 }}$ and CdTe have seen significant advances in efficiency over the last decade but may not achieve the required efficiency in the foreseeable future. The ultimate objective of the thin-film program at NASA GRC is development of a $20 \%$ AM0 thin-film device technology with high power/weight ratio.

While current thin-film single-junction efficiencies rival those of silicon, tandem devices that offer significantly higher efficiencies are in production. These tandem devices more effectively utilize solar radiation by converting shorter wavelength radiation in the upper wide-bandgap layer and passing through 
non-absorbed longer wavelength light to a narrowbandgap bottom cell material. MSP can be further enhanced by use of thin, lightweight, metal foils, or even high-temperature plastics such as polyimides. Thin-film devices are fundamentally more radiation hard simply because of their reduced thickness, this should also apply to thin-film tandems.

We have proposed and simulated a thin-film tandem device structure that can meet program objectives. The bottom cell is a $1.0 \mathrm{eV}$ CIGS device (efficiency requirements for this device have been demonstrated). ${ }^{4}$ However, there is no known device that meets the requirements of the top cell. The key requirements are: a band gap in the range 1.6$2.0 \mathrm{eV}$, an efficiency of $16-18 \%$, and transparency to transfer longer wavelengths to the bottom cell. An immediate objective is development of such a cell. Modeling and device-processing results of NASA GRC's multijunction thin-film program are highlighted.

\section{AMPS MODELLING}

Specifically the proposed structure is a 4terminal tandem as shown in figure 1. The thickness of the active layers is expected to be about $10 \mu \mathrm{m}$. The bottom polyimide can be as thick as needed for structural support, and the top polyimide (or other) layer will be designed to minimize radiation damage.

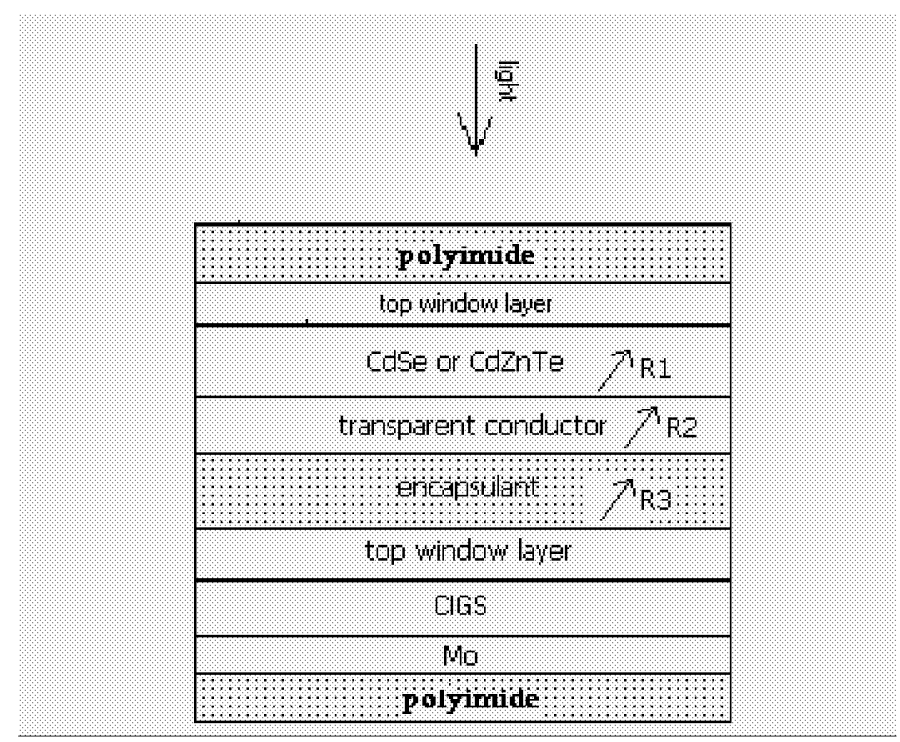

Figure 1. 4-terminal tandem device schematic.

The best $\mathrm{CdSe}$ cells to date have been in the MIS configuration with $\mathrm{ZnSe}$ as the insulating (I) layer. ${ }^{5}$ AMPS was used to model this structure. Typical values for the key parameters were taken from the literature, or by analogy to similar materials. An example of the latter is the density of states (DOS) for the conduction and valence bands that were chosen to be $1 \times 10^{18}$ and $1 \times 10^{19}$ respectively. A donor doping concentration of $1 \times 10^{14}$ was used for the

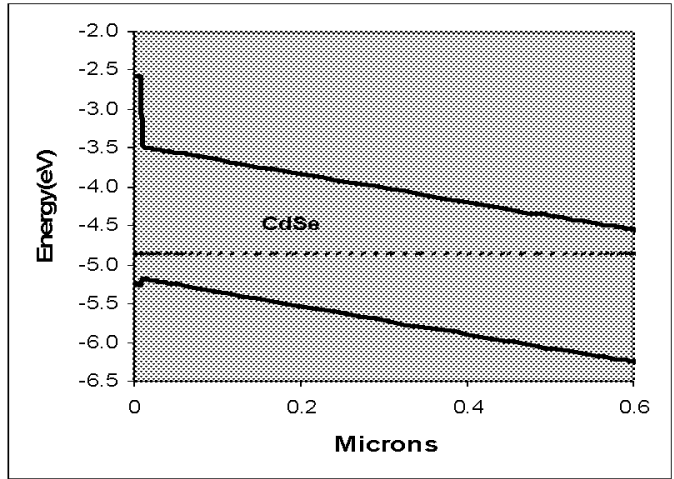

Figure 2. Equilibrium band diagram for a ZnSe/CdSe MIS structure.

$\mathrm{CdSe}$, while $1 \times 10^{4}$ was used for $\mathrm{ZnSe}$ to make it an insulator. No defects in either layer were included. The equilibrium band diagram is shown in figure 2 . As expected, the CdSe layer is completely depleted. The electron affinities used for $\mathrm{ZnSe}$ and CdSe were 3.67 and 4.56 , respectively. The conduction band offset acts as a good electron mirror, while the offset in the valence band does not impede hole flow.

The light IV curve is shown in figure 3 and is near ideal. The parameters are $V_{o c}: 1.11$ volts, $J_{s c}$ : $19.3 \mathrm{~mA} / \mathrm{cm}^{2}$ (assumed 5\% reflection loss at front), FF: 0.81 , and $\eta: 17.4 \%$. This is highly encouraging in that it indicates that a MIS structure can meet our performance requirements. A key to getting this to work is finding external contacts at the right energies. In this case the rear contact was at $0.3 \mathrm{eV}$ from the CdSe conduction band, and the front contact at $0.3 \mathrm{eV}$ from the CdSe valence band. Thus the achieved $\mathrm{Voc}$ is essentially the band gap of the CdSe (1.7) minus the sum of these two contact voltages. Experimentally the rear contact should not pose a problem, while finding a front contact with such a high energy will be difficult. The highest Voc's reported for these devices were indeed for Pt and Au contacts (up to 0.85 volts, but with low $J_{\mathrm{sc}}$ and FF) which have the

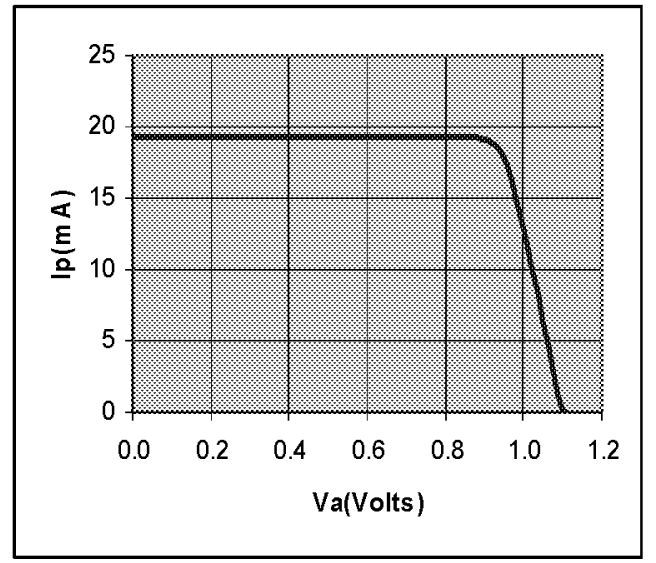

Figure 3. Simulated light IV for the $\mathrm{ZnSe} / \mathrm{CdSe}$ MIS structure with $17.4 \%$ efficiency. 
highest work functions. Also reported was a dependence of $V_{o c}$ on work function. ${ }^{5}$ Post-deposition treatment of the interface with metal was critical to achieving this; getting higher efficiencies with these structures has yet to be proven.

To further our understanding of these structures, several parameters were varied. Using electron affinities for $\mathrm{ZnSe}$ and $\mathrm{CdSe}$ of 3.67 and 4.56 respectively, the following observations were made. Changing the thickness of the $\mathrm{ZnSe}$ layer has no effect on performance. There is some disagreement in the literature on the values of electron affinities, so it is appropriate to vary this parameter. $J_{s c}$ is found to be independent of the $\mathrm{ZnSe}$ affinity, while the $\mathrm{V}_{o c}$ and FF dependence is shown in figure 4.

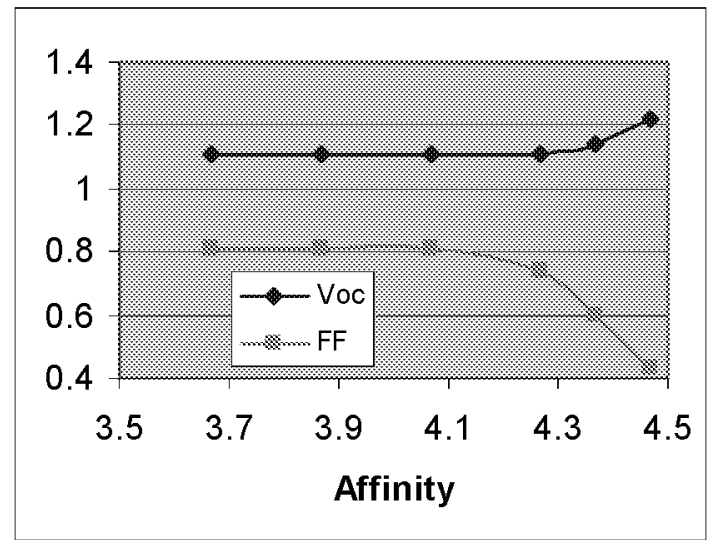

Figure 4. Voc and FF dependence on $\mathrm{ZnSe}$ affinity.

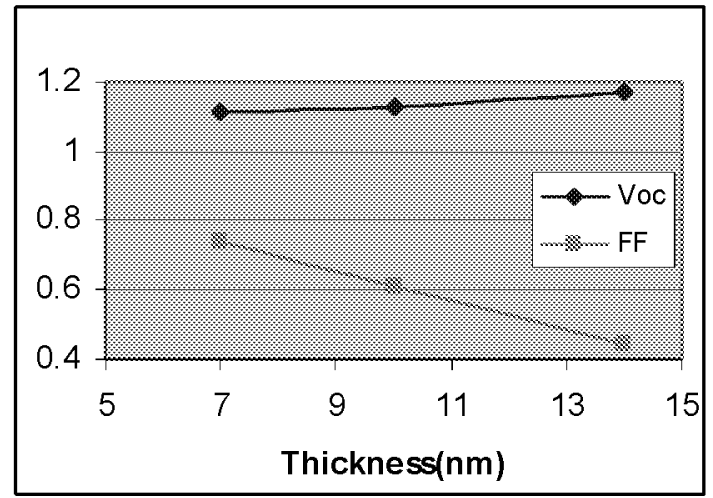

Figure 5. Dependence of $\mathrm{Voc}$ and FF on $\mathrm{ZnSe}$ thickness for a ZnSe affinity of 4.27.

As $\mathrm{ZnSe}$ affinity is increased, increasing valence band offset occurs which results in poor hole transport across the interface and declining FF. This results in a small increase in $V_{o c}$. With $\mathrm{ZnSe}$ affinity in the transition range (4.27) (see figure 5), there is now a strong $\mathrm{ZnSe}$ thickness correlation with $\mathrm{FF}$ and a weak dependence for $V_{\text {oc }}$. At a ZnSe affinity of 4.27 the valence and conduction bands each have an offset of about $0.3 \mathrm{eV}$; interference with collection begins. It is apparent that having the right band gap and electron affinity for the I layer is important. It is noteworthy that there is quite a large range of acceptable values.

It is interesting that in none of the above simulations was there a reduction in $\mathrm{J}_{\text {sc. }}$. To find the limits here we go back to the base case and systematically increase the band gap of the I layer while keeping everything else constant. Not until the I layer band gap reaches $3.37 \mathrm{eV}$ is there an effect on $\mathrm{J}_{\mathrm{sc}}$. The light and dark IV's for this case are shown in figure 6. As can be seen, forward dark current is severely restricted. $J_{s c}$ has just dropped down a bit to 18.6, but the curve shape has plummeted. Any further increase in the band gap will result in similar losses in $J_{\text {sc. }}$. The saturation of the dark current at $1 \times 10^{-12}$ in figure 6 is due to the large band gap of the $\mathrm{ZnSe}$. In figure 7 is shown the effect of the I layer band gap on dark current.

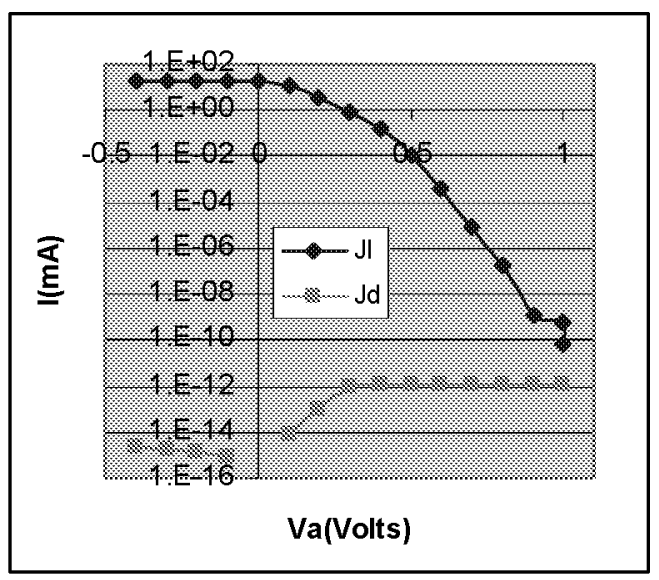

Figure 6. Light and dark IV for an I layer bandgap of $3.37 \mathrm{eV}$.

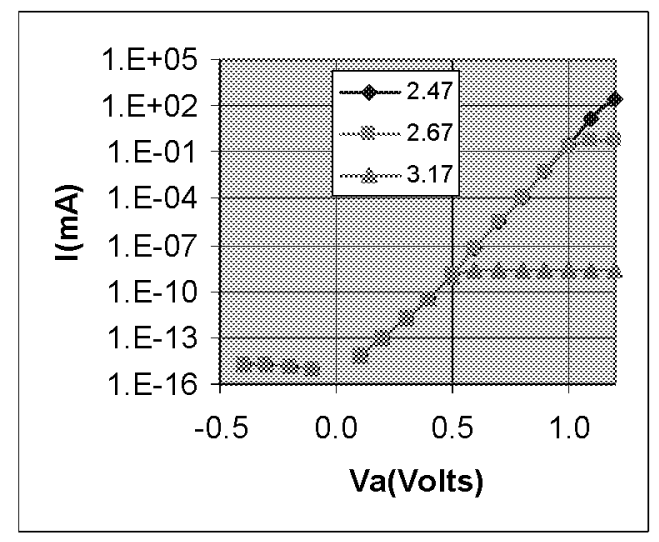

Figure 7. Dependence of dark current saturation on the energy gap of the I layer 
As can be seen, dark current flow at just over one volt is affected for the $\mathrm{ZnSe}$ band gap of $2.67 \mathrm{eV}$. While this does not affect $J_{\mathrm{sc}}, F F$ is affected (Table1). The small loss in FF for the $2.67 \mathrm{eV}$ band gap of $\mathrm{ZnSe}$ is due to the band gap itself and not on the details of band alignment. As seen in figure 4, it takes a large change in affinity to start affecting FF. Modest increases in band gap, however, result in more substantial losses. While none of this suggests that $\mathrm{ZnSe}$ is not a good choice, the implications are that a smaller band gap material would be somewhat better. This would have to be weighed against the favorable interface defect control reported for $\mathrm{ZnSe}^{7}$ In this regard $\mathrm{ZnTe}$ would seem to have a band gap advantage over $\mathrm{ZnSe}$ as an I layer, although a disadvantage because of the toxicity of Te.

Table 1. MIS device properties as a function of Insulator-layer bandgap.

\begin{tabular}{|c|c|c|c|c|}
\hline $\mathbf{E}_{\mathbf{g}}$ & $\mathbf{J}_{\mathbf{s c}}$ & $\mathbf{V}_{\text {oc }}$ & FF & Eff. ( $\boldsymbol{\eta})$ \\
\hline 2.47 & 19.3 & 1.11 & .89 & 19.0 \\
\hline 2.67 & 19.3 & 1.11 & .81 & 17.4 \\
\hline 3.17 & 19.3 & 1.11 & .37 & 7.9 \\
\hline
\end{tabular}

While there remain issues on details to be resolved for the MIS structure we are satisfied that good performance can be achieved under the right circumstances. At the outset we were concerned that sensitivity to the strong thickness dependence of tunneling for a true MIS structure would be troublesome, but these devices do not require tunneling to function well. $\mathrm{ZnSe}$ is not behaving as an I layer, but rather as a type of heterojunction contact to CdSe. Up to this point, we have ignored optical losses due to the metal contact. Metals have not been used as transparent conductors in solar cells for this reason. While this is a concern here, there may be mitigating circumstances that relax that concern. As will be discussed below, the "M" in the MIS structure may also be a misnomer. That is, the metal, particularly $\mathrm{Cu}$ may be reacting with the semiconductor layers. This may be its most important role, and once this is accomplished by a small quantity of metal, the top of the device could be finished with a standard transparent conductor such as $\mathrm{ZnO}$ with proper opto-electronic properties.

In fact this leads us back to our concept of a device structure p-transparent contact/absorber/ntransparent contact. Following up on what we have learned about the MIS structure, a metal/ZnSe structure would serve as our p-transparent contact. This should serve as a valid starting point for developing our devices, particularly the absorbers. Eventually, however, we will have to replace this $p$ contact with one with larger effective contact energy to achieve high $V_{\text {oc }}$.

The Culn $\mathrm{Ga}_{1-x} \mathrm{Se}_{2}$ (CIGS) bottom cell technology already exists. This is certainly the case on glass substrates where efficiencies in excess of $15 \%$ are routine. Some effort has gone into developing CIGS on metal foil and polyimide, ${ }^{8}$ but performance is somewhat poorer. Nevertheless this can be improved upon with further effort, and we thus will focus our efforts under this project on the top cell. This is where innovation is needed because there is no known thin-film device with a high band gap and high efficiency. Below we report progress on development of this top cell. In addition to requiring high efficiency and light-weight there is the added requirement for a tandem device structure that it be transparent to longer wavelengths. Our approach is to break these down into individual components and address each technical issue in turn.

As shown in figure 8 , performing these simulations at AMO results in projected efficiencies in excess of $20 \%-13.8 \%$ is contributed by a top cell with band gap of $1.55 \mathrm{eV}$, and $6.3 \%$ is contributed by the underlying CIGS cell. In this case we argued that the top cell could be $\mathrm{Cd}_{1-x} \mathrm{Zn}_{\mathrm{x}} \mathrm{Te}(\mathrm{CZT})$ with a small amount of zinc that should not change the electronic properties significantly from those of CdTe that were used in the simulation. As the band gap of the top cell is increased beyond 1.55 by adding more $\mathrm{Zn}$, or using $\mathrm{CdSe}$ with its $1.7 \mathrm{eV}$ band gap, the expected efficiency moves above $20 \%$. Thus our primary objective is to demonstrate a top cell from either of these material options with an AMO efficiency of $13 \%$ or more.

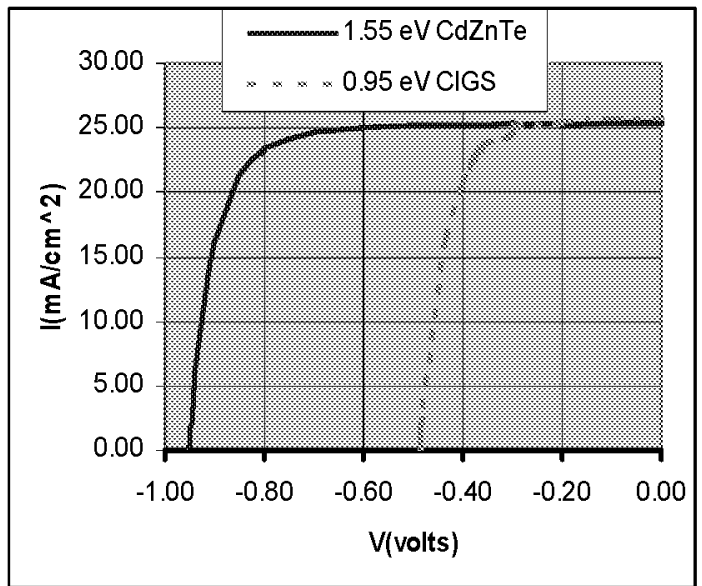

Figure 8. Simulated AMO IV curves for a tandem device consisting of a $1.55 \mathrm{EV}$ top cell and $0.95 \mathrm{eV}$ bottom CIGS cell. Tandem efficiency is $20.1 \%$.

\section{PROCESSING OF TOP-CELL MATERIALS}

We are pursuing Culn ${ }_{1-x} \mathrm{Ga}_{x} \mathrm{~S}_{2}$ (CIGS2) (FSEC), CdSe (USF), and CZT (USF) as candidate absorbers for the top cell. (ClGS2) thin films were prepared by sulfurization of DC magnetron-sputtered $\mathrm{CuGa} / \mathrm{ln}$ precursor on stainless steel foil substrates. The modeling and fabrication effort at USF is focused on $\mathrm{CdSe}$ and CZT as primary candidates. The progress that we discuss below will be for CdSe. Much of the effort thus far on CZT has been on material processing and characterization. 


\section{CdSe Fabrication}

To check the optical performance of our CdSe films we deposited a $1600 \mathrm{~nm}$ thick film on glass and measured its transmission profile. As seen in figure 9 , $\sim 80 \%$ is transmitted in the wavelength range above $750 \mathrm{~nm}$ that is the domain of the underlying CIGS cell. This is only $5 \%$ lower than the $85 \%$ figure assumed in the simulations for efficiency. This is very encouraging because this film is thicker than the CdSe film we expect to use; no attempt was made to reduce reflection losses. Much of the $20 \%$ loss is expected to be reflection that will be reduced when top layers are present. When suitable AR layers are determined, a further reduction of losses is expected.

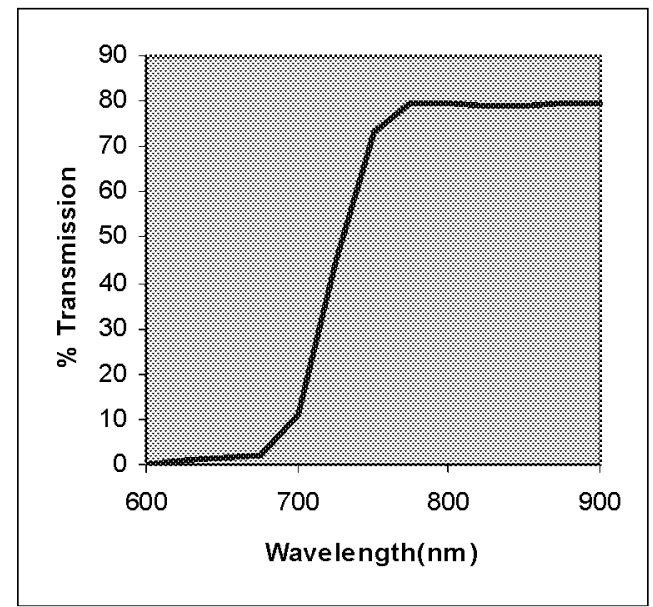

Figure 9. Transmission profile of a $1600 \mathrm{~nm}$ CdSe film on glass.

Our initial fabrication efforts centered upon the metal-insulator-semiconductor (MIS) structure. We used a transparent conductor as the growth surface. The device structure is $\mathrm{Cu} / \mathrm{ZnSe} / \mathrm{CdSe} / \mathrm{TC}$. The $\mathrm{CdSe}$ substrate temperature was varied over the $450-600^{\circ} \mathrm{C}$ range while the substrate temperature for $\mathrm{ZnSe}$ deposition was $200^{\circ} \mathrm{C}$. The $\mathrm{ZnSe}$ and $\mathrm{Cu}$ layers are deposited sequentially by PVD without breaking vacuum between. However, they are deposited in a different system from the CdSe, and thus the CdSe surface is exposed to ambient prior to deposition of the Ml contact layers. The $\mathrm{ZnSe}$ is a continuous layer, while the metal is deposited through a shadow mask.

Since our primary concern is to demonstrate high electronic quality $\mathrm{CdSe}$, we have focused our efforts on demonstrating high short circuit currents in devices. $J_{s c}$ is typically an indicator of bulk properties, while $V_{o c}$ and $F F$ in thin film devices are often more affected by interface properties and contact properties. For example, we expect that the low $V_{o c}$ 's in these devices are primarily the result of the effective contact energies of the contacts and have little to do with the CdSe. This is more likely to be the case if we are seeing good $J_{s c}$ 's indicating good prope'rties for the CdSe bulk. Using $J_{s c}$ as our figure-of-merit we proceeded to vary the $\mathrm{CdSe}$ deposition parameters to optimize its electronic properties, specifically $J_{\text {sc. }}$ In figure 10 we show $Q E$ spectral response of a device with the highest $J_{s c}$ that we have achieved to date. Calibration of $Q E$ is accomplished by calibrating our light source against a Si reference cell. $J_{s c}$ is determined by integrating the external QE spectrum and is found to be 14.7 $\mathrm{mA} / \mathrm{cm}^{2}$. This is the actually measured $J_{\mathrm{sc}}$ of the device.

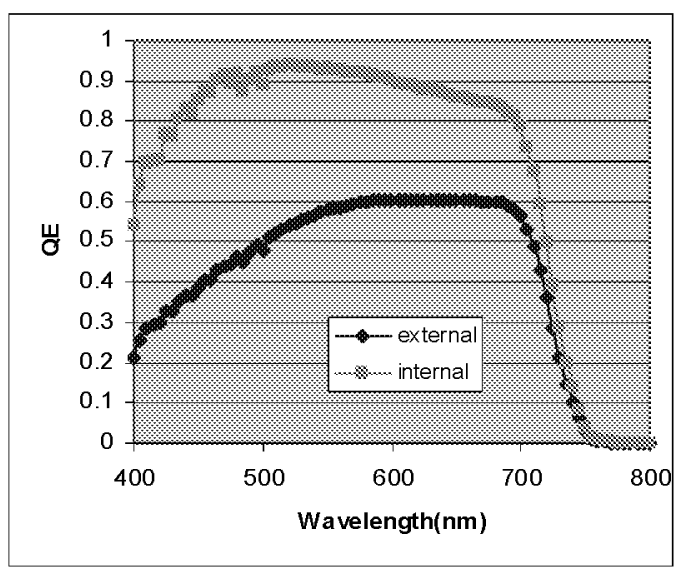

Figure 10. External and internal $Q E$ of a $\mathrm{Cu} / \mathrm{ZnSe} / \mathrm{CdSe} / \mathrm{TC}$ device.

When the external QE spectrum in figure 10 is normalized against the transmission of the $\mathrm{Cu} / \mathrm{ZnSe}$ layer, the internal QE spectrum shown in figure 10 results. Integration of this spectrum results in an equivalent internally generated $J_{s c}$ of $18.3 \mathrm{~mA} / \mathrm{cm}^{2}$. This is within one $\mathrm{mA} / \mathrm{cm}^{2}$ of the Jsc for the simulated $17.4 \%$ MIS device in Table 1. As such this result is a strong indication that we are making very good electronic quality $\mathrm{CdSe}$. Since the $\mathrm{CdSe}$ is on a transparent conductor this represents a big step forward toward achieving our overall objectives. The next focus of our efforts is development of top contact layers. This is where higher $V_{o c}$ 's will come from; higher $V_{o c}$ 's will increase the internal fields that should further tweak $J_{s c}$ values as well as FF's.

\section{CIGS2 Thin Films on Metal Foil}

Substrates used in this study included $127 \mu \mathrm{m}$ and $20 \mu \mathrm{m}$ thick bright-annealed stainless steel (SS) foils and $25 \mu \mathrm{m}$ thick titanium foils. The results discussed herein are for samples on $127 \mu \mathrm{m}$ thick SS foils. $\mathrm{CuGa}$ and In precursor layers were $\mathrm{DC}$ magnetron-sputter deposited on Mo-coated SS foils with elemental ratio $\mathrm{Cu} /(\mathrm{In}+\mathrm{Ga})$ of $\sim 1.4$. Metallic precursors were homogenized by heating the samples to $135^{\circ} \mathrm{C}$ for 25 minutes in argon gas flow. Culn ${ }_{1-x} \mathrm{Ga}_{\mathrm{x}} \mathrm{S}_{2}$ (CIGS2) thin films were prepared by sulfurization of the CuGa/ln precursor films in $\mathrm{Ar}: \mathrm{H}_{2} \mathrm{~S}$ (4\%) gas mixture at $475{ }^{\circ} \mathrm{C}$. CIGS2 thin films grew with a chalcopyrite Culn ${ }_{0.7} \mathrm{Ga}_{0.3} \mathrm{~S}_{2}$ phase with $\mathrm{a}=5.67$ $A$ and $c=11.34 \AA$ and preferred $\{112\}$ orientation. 
Cux $\mathrm{S}$ phase segregating at the surface was etched away with a $10 \%$ aqueous $\mathrm{KCN}$ solution. CIGS2 solar cells were completed by deposition of CdS heterojunctions by chemical bath deposition, transparent-conducting $\mathrm{ZnO} / \mathrm{ZnO}: \mathrm{Al}$ window bilayer by RF sputtering, and vacuum deposition of $\mathrm{Ni} / \mathrm{Al}$ contact fingers through metal mask. CIGS2 thin films and solar cells were characterized by atomic force microscopy (AFM), scanning electron microscopy (SEM), X-ray diffraction (XRD), C-V, I-V, microphotoluminescence (micro-PL) and $\mathrm{QE}$ techniques.

Non-contact AFM image showed the unetched CIGS2 films to consist of compactly packed, well faceted grains having size ranging from $1-3 \mu \mathrm{m}$ with a roughness of $0.19 \mu \mathrm{m}$ (Fig. 11). SEM image of unetched sample also showed large, well faceted grains. Thus the Cu-rich stoichiometry during the growth of CIGS2 films resulted in an improved morphology.

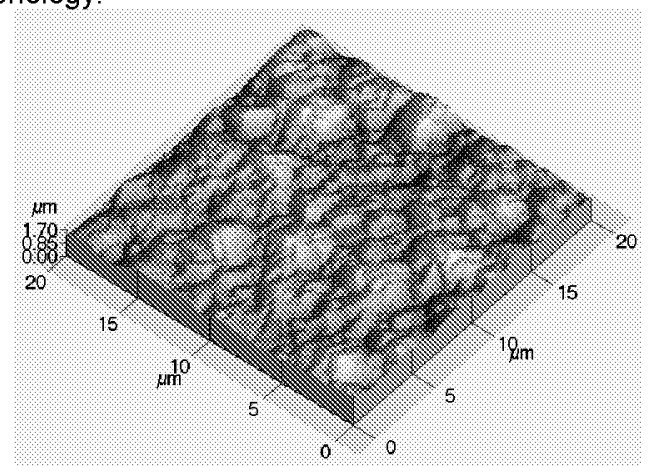

Figure 11. Non-contact AFM image of an unetched CIGS2 film.

SEM of etched CIGS2 films display a considerably rougher surface with protrusions and valleys. $\mathrm{XRD}$ and EPMA analysis do not show evidence of compositional or structural fluctuations. Inhomogeneous broadening, and variation of peak position and amplitude of micro-PL signal variations may therefore be attributed to the rough morphology of the etched films. The CIGS2 carrier density extracted from the CV data was found to vary in the mid- $10^{16} \mathrm{~cm}^{-3}$ range and relatively constant between 80 and $180 \mathrm{~nm}$ from the junction. PV parameters of the best CIGS2 solar cell on SS flexible foil measured at NASA GRC under AMO conditions were $V_{o c}=$ $802.9 \mathrm{mV}, \mathrm{J}_{\mathrm{sc}}=25.07 \mathrm{~mA} / \mathrm{cm}^{2}, \mathrm{FF}=60.06 \%$, and $\eta=$ $8.84 \%$. Quantum efficiency characteristics gave a band gap of $1.50 \mathrm{eV}$ and only a modest CdS loss.

\section{CONCLUSIONS}

Considerable progress has been made with CdSe using a MIS structure. We have modeled this structure and demonstrated that this structure can meet our efficiency objectives. Guided by these results we have utilized a metal/ZnSe/CdSe/TC structure as our device format for evaluating $\mathrm{CdSe}$. External and internal $J_{\mathrm{sc}}$ 's of 14.7 and $18.3 \mathrm{~mA} / \mathrm{cm}^{2}$ respectively have been demonstrated. This is a significant result in that it is on a transparent contact and indicates that we are able to deposit high electronic-quality CdSe on transparent conductors. We have demonstrated $80 \%$ transmission of light for the bottom cell through $1600 \mathrm{~nm}$ CdSe films. This is within reach of our target of $85 \%$ through use of $A R$ coatings.

Unetched (CIGS2) thin films, prepared by sulfurization of DC magnetron-sputtered $\mathrm{CuGa} / \mathrm{ln}$ precursor on stainless steel foil substrates, consisted of compactly packed, well faceted grains having size ranging from $1-3 \mu \mathrm{m}$ with a roughness of $0.19 \mu \mathrm{m}$. The etched CIGS2 films showed a considerably rougher surface with protrusions and valleys. The best efficiency of CIGS2 solar cell on SS flexible foil measured at NASA GRC was $8.84 \%$ AM0.

\section{REFERENCES}

1. S.G. Bailey and D.J. Flood, "Space Photovoltaics," Prog. Photovolt. Res. Appl. Vol. 6, pp. 1-14 (1998).

2. P. A. Iles, "Evolution of Space Solar Cells," Solar Energy Materials and Solar Cells Vol. 68, pp. 1-13 (2001).

3. D.J. Hoffman, T.W. Kerslake, A.F. Hepp, M.K. Jacobs, and D. Ponnusamy, "Thin-Film Photovoltaic Solar Array Parametric Assessment," Proceedings $35^{\text {th }}$ IECEC, AIAA, Washington, D.C., Vol. 1, pp. 670-680, AIAA-00-2919 (2000).

4. H.W. Schock, and R. Noufi, "CIGS-based Solar Cells for the Next Millennium," Prog. Photovolt. Res. Appl., Vol. 8, pp. 151-160 (2000).

5. H. Richter, "Development of $p, n$ Heterojunctions Based on Thin Polycrystalline CdSe Films," Proceedings of the $20^{\text {th }}$ IEEE PV Specialist Conference, IEEE, New York, NY, Vol. 2, pp. 15371541 (1988).

\section{S.J. Fonash, www.psu.edu/dept/AMPS/, (2000).}

7. D. Bonnet and E. Rickus, "The CdSe Thin-Film Solar Cell," Proceedings of the $14^{\text {th }}$ IEEE PV Specialist Conference, IEEE, New York, NY, pp. 629632 (1980).

8. D. Rudmann, F.-J. Haug, M. Krejci, H. Zogg and A. Tiwari, "Development of Flexible $\mathrm{Cu}(\mathrm{In}, \mathrm{Ga}) \mathrm{Se}_{2}$ Solar Cells on Polymers with Lift-off Processes," Proceedings of the $16^{\text {th }}$ European PVSEC, James and James (Science Publishers) Ltd., London, UK, Vol. 1, pp. 298-301(2000) 


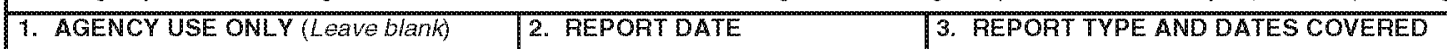

\begin{tabular}{|l|l|l|}
\hline & October 2002 & Technical Memorandum \\
\hline
\end{tabular}

$\begin{array}{ll}\text { 4. TITLE AND SUBTITLE } & \text { FUNDING NUMBERS }\end{array}$

Multi-Junction Thin-Film Solar Cells On Flexible Substrates For Space Power

6. ABTHOR(S)

WU-755-A4-00-10

Aloysius F. Hepp, Mark Smith, John H. Scofield, John E. Dickman,

Gregory B. Lush, Donald L. Morel, Christos Ferekides, and Neelkanth G. Dhere

7. PEAFORMING ORGANIZATION NAME(S) AND ADDRESS(ES)

National Aeronautics and Space Administration

John H. Glenn Research Center at Lewis Field

Cleveland, Ohio 44135-3191

8. PERFORMING ORGANIZATION

REPORT NUMBER

E-13528

9. SPONSORING/MONITORING AGENCY NAME(S) AND ADDRESS(ES)

10. SPONSORING/MONITORING AGENCY REPORT NUMBER

National Aeronautics and Space Administration

Washington, DC 20546-0001

NASA TM-2002-211834

IECEC-2002--20155

\section{SUPPLEMENTARY NOTES}

Prepared for the 37th Intersociety Energy Conversion Engineering Conference sponsored by the Institute of Electrical and Electronics Engineers, Electron Devices Society, Washington, DC, July 28-August 2, 2002. Aloysius F. Hepp and John E. Dickman, NASA Glemn Research Center; Mark Smith, Ohio Aerospace Institute, Brook Park, Ohio; John H. Scofield, Oberlin College, Physics Department, Oberlin, Ohio; Gregory B. Lush, University of Texas at El Paso, Department of Electrical Engineering, El Paso, Texas; Donald L. Morel and Christos Ferekides, University of South Florida, Department of Electrical Engineering, Tampa, Florida; and Neelkanth G. Dhere, University of Central Florida, Florida Solar Fnergy Center, Orlando, Florida. Responsible person, Aloysius F. Hepp, organization code 5410, 216-433-3835.

\begin{tabular}{l|l} 
12a. DISTRIBUTION/AVALABILITY STATEMENT & 12b. DISTRIBUTION CODE
\end{tabular}

Unclassified-Unlimited

Subject Category: 25

Distribution: Nonstandard

Available electronically at mo/glragrcmasia.sow

This publication is available from the NASA Center for AeroSpace Information, 301-621-0390.

13. ABSTRACT (Maximum 200 words)

The ultimate objective of the thin-film program at NASA GRC is development of a 20 percent AMO thin-film device technology with high power/weight ratio. Several approaches are outlined to improve overall device efficiency and power/weight ratio. One approach involves the use of very lightweight flexible substrates such as polyimides

(i.e., Kapton ${ }^{\mathrm{TM}}$ ) or metal foil. Also, a compound semiconductor tandem device structure that can meet this objective is proposed and simulated using Analysis of Microelectronic and Photonic Structures (AMPS). AMPS modeling of current devices in tandem format indicate that $\mathrm{AMO}$ efficiencies near 20 percent can be achieved. And with improvements in materials, efficiencies approaching 25 percent are achievable. Several important technical issues need to be resolved to realize these complex devices: development of a wide bandgap material with good electronic properties, development of transparent contacts, and targeting a 2-terminal device structure (with more complicated processing and tunnel junction) or 4-terminal device. Recent progress in the NASA GRC program is outlined.

\section{SUBJECT TERMS}

15. NUMBER OF PAGES

Tellurides; Cadmium selenides; thin films; solar cells; MIS semiconductors

17. SECURITY CLASSIFICATION OF REPORT

Unclassified

NSN 7540-01-280-5500
18. SECURITY CLASSIFICATION OF THIS PAGE

Unclassified
19. SECURITY CLASSIFICATION OF ABSTRACT

Unclassified
16. PRICE CODE

20. LIMITATION OF ABSTRACT

